\title{
BUSINESS MODEL CANVAS (BMC) APPROACH FOR TOURISM MANAGEMENT STRATEGY OF THE TOP SELFIE KRAGILAN, MT. MERBABU NATIONAL PARK
}

\author{
Johan SETIAWAN* \\ Sebelas Maret University, Doctoral Program of Environmental Science, Indonesia, e-mail: johansetiawan@student.uns.ac.id
}

\section{MTh Sri BUDIASTUTI}

Sebelas Maret University, Faculty of Agriculture, Department of Agrotechnology, Indonesia, e-mail: mariatheresia@staff.uns.ac.id

\section{Evi GRAVITIANI}

Sebelas Maret University, Faculty of Economics, Department of Economic Development, Indonesia, e-mail: evigravitiani_fe@staff.uns.ac.id

\author{
Prabang SETYONO
}

Sebelas Maret University, Faculty of Mathematics and Science, Department of Biology, Indonesia, e-mail: prabangsetyono@staff.uns.ac.id

\author{
Citation: Setiawan, J., Budiastuti, M.S., Gravitiani, E., \& Setyono, P. (2021). BUSINESS MODEL CANVAS (BMC) APPROACH \\ FOR TOURISM MANAGEMENT STRATEGY OF THE TOP SELFIE KRAGILAN, MT. MERBABU NATIONAL PARK. \\ GeoJournal of Tourism and Geosites, 35(2), 297-303. https://doi.org/10.30892/gtg.35205-651
}

\begin{abstract}
The tourist spot of the Top Selfie Kragilan, Mt. Merbabu National Park, a conservation area in Indonesia has not been managed with a business strategy despite the community initiatives increase to utilize the surrounding tourist spots for their livelihood. The study aimed at formulating the tourism business management strategy using Business Model Canvas (BMC) and Strength-Weakness-Opportunity-Threat (SWOT) approaches. BMC modeling used nine aspects, namely customer segments, value propositions, channels, customer relationships, revenue streams, key resources, key activities, key partners, and cost structure; then analyzed using SWOT approaches. A total of 377 respondents were interviewed to collect the data. The results showed that every aspect of the old business model has been added or innovated according to the analysis of internal and external factors. Also, there has been a "meeting point" between market expectations, the value offered, and the promotional channels used. The combined strategy of Aggressive (S-O) and Diversification (S-T) should be applied to mitigate damage impact, conserve the natural resources, and arranging visits and selfie vehicles/ photo spot to boost revenue streams.
\end{abstract}

Key words: Business Model Canvas, Ecotourism, Community Based Tourism, Selfies, National Parks

$* \quad * \quad * \quad * \quad * \quad *$

\section{INTRODUCTION}

National park is a natural conservation area with native ecosystem, which is used for research, science, education, culture, tourism as well as recreation. Besides protection and preservation, Conservation Areas are also expected to accommodate multiple mandates, such as ecological and recreational functions (Shi et al., 2019). One of the well-known National Parks in Indonesia is Mount Merbabu National Park (TNGMb), which is managed by a zoning system, such as Core, Jungle, Use, Rehabilitation, and Traditional Zones. The Traditional Zone is directly adjacent to the buffer village, an d it is currently used for Limited Tourism activities. Furthermore, the activities within this zone can be conducted with community groups through a partnership cooperation agreement mechanism. Various systems and regulations are determined unilaterally by the government, such as zoning (Kodir et al., 2019). The geographical information of the study site is presented in Figure 1. Recent developments in TNGMb show an increase in community initiatives to utilize the tourist spots of the Traditional Zone. Similar trends in the development of community-based natural tourism were conveyed by Lonn et al. (2018), where tourist activities were reported to be increased, especially in tropical developing countries. Increased visit rate in many National Parks pose a major threat to environmental integrity because the process requires costly management and monitoring initiatives to minimize negative impacts (Shi et al., 2019). Not only in Indonesia but also the existence of a national park causes more complex problems for indigenous peoples and local communities (Perez, 2018).

Kragilan Pine Forest (called Top Selfie) is TNGMb Traditional Zone that has currently developed into a tourism site. At least 140,100 tourists in 2018 and 135,900 in 2019 have visited this attraction center. The management of Top Selfie by Kragilan Hamlet community is based on mutual agreement between National Park Agency and Ecotourism engagement group (Pokdarwis). This management is conducted communally and tends to be responsive without careful planning.

Also, the impression of a trial and error projects can be seen in the construction of a selfie photo spot that is disorganized and leaves a full and dirty impression. Tourism management in nature reserves should not be performed haphazardly as the cost of repairing damaged ecosystems is much higher. However, it is hoped that at least one "neutral" or "coexistence" 
relationship will be achieved (Cochard, 2017; Shi et al., 2019). It should also be conducted carefully to provide benefits for the community, by focusing on reservation aspects and considering the improvement of welfare(Cobbinah et al., 2017). Making a linkage between the process conservation and educational combined with wildlife tourism, a balance between tourist needs, ecological requirements and expectations of local community could be achieved (Chakrabarty et al., 2019). Organizations that want to realize sustainable business ventures need creative modeling instrument (Joyce and Paquin, 2016) since some experts offer several development models with various approaches. Similarly, Butler (1980) constructed a model based on developmental stages, (Yoon and Uysal, 2005) used a stakeholder approach, and Dwyer and Kim (2003) used resource variables, situational conditions, as well as competitiveness and Business Model Canvas (BMC) approach (Osterwalder et al., 2010). BMC approach (Osterwalder et al., 2010) is good because it identifies the most essential parts of business development, while producing a solid strategy and ensuring sustainability (Toro-Jarrín et al., 2016). There are nine blocks of BMC aspects analyzed, namely 1) Customer Segment, 2) Value Propositions, 3) Channels, 4) Customer Relationships, 5) Revenue Streams, 6) Key Resources, 7) Key Activities, 8) Key Partners, 9) Cost Structure. These aspects illustrate the rational reasons for managerial creativity, delivery, and value capturing (Osterwalder et al., 2010). Following

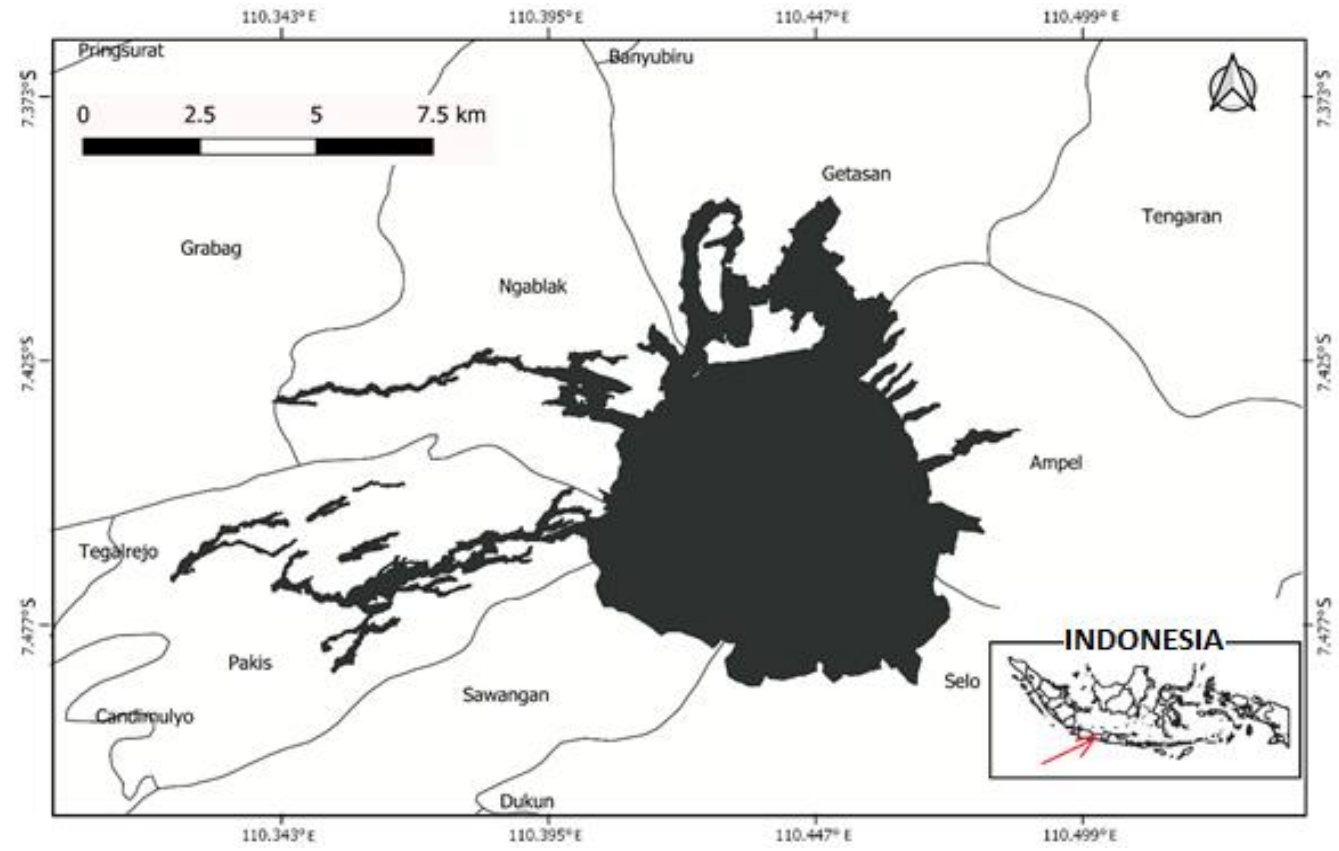

Figure 1. The geographical position of the study site with the surrounding occupied districts the adopted problems and approaches, this study aims to determine the Top Selfie tourism development strategy using BMC. This is integrated with additional instruments, techniques and methodologies (Daou et al., 2020), namely Strength, Weakness, Opportunity, Threat (SWOT) analysis. The SWOT analysis is based on logic that can optimize strengths and possibilities, as well as serve as a mechanism to mitigate vulnerabilities in the organization's body and decrease the effect of risks that occur and must be faced. The strategic decision -making process is always linked to growth, mission, objectives, and strategy

(Sanagustín Fons et al., 2011). Therefore, the business model is more dynamic in integrating all aspects of implementation, and evaluation process to compile the Top Selfie tourism management business model.

\section{MATERIALS AND METHODS}

This study was conducted in Top Selfie, Traditional Zone, Mount Merbabu National Park, Central Java Province, Indonesia (Figure 1). Figure 1 shows that The Mt. Merbabu National Park occupied 6 districts, namely Sawangan, Selo, Ampel, Getasan, Ngablak and Pakis with the total area of 5,725 Ha. The study was carried out from August to December 2019, and it combined both primary and secondary data. Besides direct observation, primary data collection was performed by using tourist questionnaires, which were distributed with an error limit of $5 \%$ and was calculated using Slovin formula $n=N /\left(1+N e^{2}\right)$ (Ryan, 2013), where $\mathrm{n}=$ sample number; $\mathrm{N}=$ population number; and e= error limit decided by the researcher. From 22,457 population, the Slovin formula resulted the number of samples for Top Selfie was 393 people.

This study used a combination of qualitative and quantitative descriptive methods. Data from field observations and interviews were elaborated with quantitative data from surveys on tourists and were analyzed in nine aspects of BMC. Each element in these blocks is then analyzed for its strengths, weaknesses, opportunities, and threats to formulate a new business model. The flow chart of the research steps is presented in Figure 2.

\section{RESULTS AND DISCUSSION}

\section{Customer Segments}

Fan et al. (2019) stated that by understanding the types of tourists, managers can determine the variety of values created. Customer Segments is the heart of any business model (Osterwalder et al., 2010), because the market inspire other aspects. Meanwhile, the survey results of 393 tourists show that the current Top Selfie tourism market segment consists majorly of young people from the millennial generation. Therefore, it was reported that $67 \%$ of respondents were under 25 years old, $17 \%$ were aged between 26 to 35 years and $16 \%$ were over 35 years old. From the total respondents, it is known that $66 \%$ were unmarried, $47 \%$ were in school/college, $47 \%$ were already working and $6 \%$ were housewives. Judging from the original city, about $40 \%$ of respondents were from regencies in Mt. Merbabu foot, $43 \%$ were from Central Java, 14\% from Yogyakarta and 3\% from outside 
the mentioned locations. It is important to establish the sociodemographic characteristics of ecotourists to understand their motivations and develop management policies that preserve the environment of these destinations (Carvache-Franco et al., 2020).

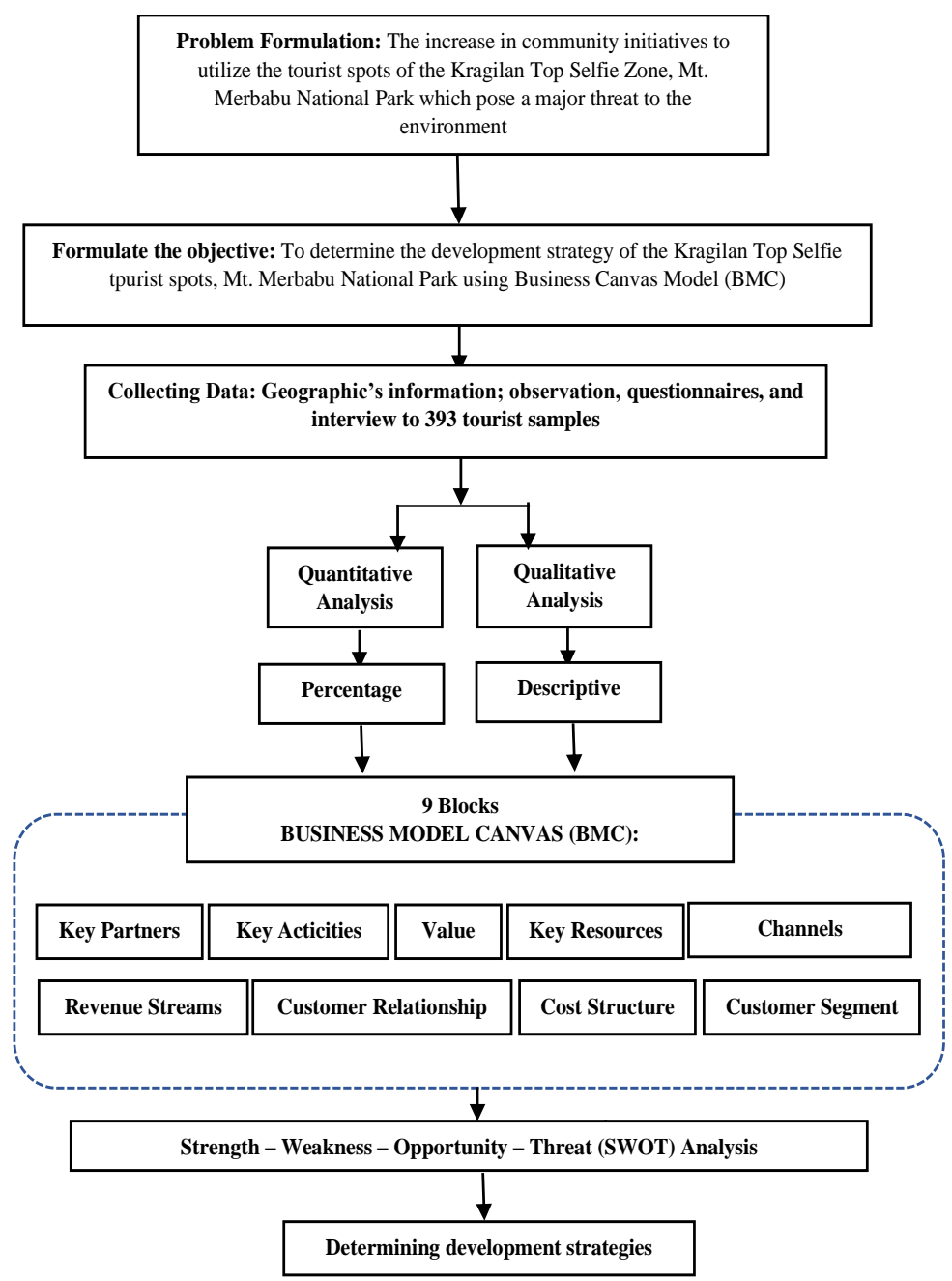

Figure 2. Flow chart of research steps

The profile of young tourists is large in the pocket market but usually has low purchasing power. Although these powers are low compared to the older generation, but they are more consistent with their enjoyment (Cavagnaro et al., 2018). The characteristics of the millennial generation are very dependent on technology information (Hajli et al., 2018), social networking (Oliveira et al., 2020), creating buzz through video posting, tweeting, and sharing links (Cavagnaro et al., 2018). The SWOT analysis of costumer segment is presented in Table 1. It is shown in Table 1 the strategy should be developed in this aspect is the Aggressive (S-O) method, which focuses on programs to capture and maintain the current market while expanding the promotions. The manager does not need to join other markets since opportunities are still wide open.

\section{Value Proposition}

The SWOT analysis on value propositions aspects of BMC Top Selfie is presented in Table 2. Table 2 figures out that the high interest in photo tourism is also influenced by the cyberculture that is currently developing among the younger generation and urban community. Selfie culture is a phenomenon easily found in urban society (Fan et al., 2019), where the tourist has a preference for the spontaneous exchange of photos and experiences (Oliveira et al., 2020) as well as possesses a high presence on the social media platforms. It is a great opportunity for Top selfie because in the future cyberculture is still coloring people's lives. Based on Table 2, the strategy applied to the Value Propositions aspect can be the combination of Aggressive (S-O) and

Turn Around (W-O). These strategies optimize existing resources and fix deficiencies to seize bigger opportunities. Top Selfie must maintain the nature-based tourism segment, and innovation in attractions should be explored to avoid boredom as well as face other competitors. It is necessary to adjust the flow of visitors and/or limit the quota because their peak value is too high, and in consequence, obtaining a good photo angle will be difficult.

Table 1. SWOT Analysis of Customer Segments Aspects of BMC Top Selfie

\begin{tabular}{|c|c|c|c|}
\hline Strength $(\mathrm{S})$ & Weakness $(\mathrm{W})$ & Opportunity $(\mathrm{O})$ & Threat $(\mathrm{T})$ \\
\hline $\begin{array}{c}\text { 1. The segment of millennials } \\
\text { 2. Local tourists }\end{array}$ & Low purchasing power & The millennial's is a large market pocket & The millenial's is very critical \\
\hline
\end{tabular}

Table 2. SWOT Analysis on Value Propositions Aspects of BMC

\begin{tabular}{|l|l|l|l|}
\hline \multicolumn{1}{|c|}{ Strength (S) } & \multicolumn{1}{|c|}{ Weakness (W) } & \multicolumn{1}{c|}{ Opportunity (O) } & \multicolumn{1}{c|}{ Threat (T) } \\
\hline $\begin{array}{l}\text { 1. Forest-Mountain landscape view } \\
\text { 2. Various kinds of photo spot }\end{array}$ & $\begin{array}{l}\text { 1. Narrow Valley } \\
\text { 2. The photo spots are not well organized } \\
\text { 3. Too crowded during peak seasons }\end{array}$ & $\begin{array}{l}\text { 1. Great market pocket } \\
\text { 2. The selfie trend is still very high }\end{array}$ & $\begin{array}{l}\text { 1. Similar destinations } \\
\text { 2.Photo spots are easy to imitate }\end{array}$ \\
\hline
\end{tabular}

\section{Channels}

Table 3 presents the analysis of SWOT channels aspect on BMC. It describes that the channels for the best selfie advertising are currently powered by social media and word of mouth marketing. Although simple and inexpensive, these channels have proven to be very effective. In addition, the survey also found out that $56 \%$ of respondents knew the Top Selfie from social media, while $43 \%$ obtained information from friends/family and only $2 \%$ respond from other media. Currently, digital empowerment and smartphone proliferation have effectively connected tourists at home with their respective destinations. Therefore, marketing through word of mouth and free publications by visitors on social media is very effective. Considering the importance of identifying the pull and push factors motivating the choice of tourist destinations, social media platforms are very useful for local destination marketers, as a driving instrument for destination determination (del Mar 
Gálvez-Rodríguez et al., 2020). Based on Table 3, the strategy should be developed in this aspect is aggressive (S-O), which focuses on programs to continue the proven power of social media publication, coupled with strengthening channels.

Tabel 3. The Analysis of SWOT Channels Aspect on BMC Top Selfie

\begin{tabular}{|l|l|l|l|}
\hline \multicolumn{1}{|c|}{ Strength $(\mathrm{S})$} & \multicolumn{1}{|c|}{ Weakness (W) } & \multicolumn{1}{c|}{ Opportunity (O) } & \multicolumn{1}{c|}{ Threat (T) } \\
\hline $\begin{array}{l}\text { 1. Social media } \\
\text { 2. Word of mouth }\end{array}$ & Uncontrolled publication & $\begin{array}{l}\text { 1. Social media publications } \\
\text { 2. IT optimization }\end{array}$ & Bad Publication \\
\hline
\end{tabular}

Table 4. SWOT analysis on customer relationships aspects of Top Selfie BMC

\begin{tabular}{|l|l|l|l|}
\hline \multicolumn{1}{|c|}{ Strength $(\mathrm{S})$} & \multicolumn{1}{|c|}{ Weakness $(\mathrm{W})$} & \multicolumn{1}{c|}{ Opportunity $(\mathrm{O})$} & \multicolumn{1}{c|}{ Threat $(\mathrm{T})$} \\
\hline 1. On site excellent services & 1. No feedback / suggestions & 1. Build relationships / networking & Others Competitors \\
2. Direct interaction & 2. There is no service standardization & 2. Bundling with other tourist attractions & provide better service \\
\hline
\end{tabular}

\section{Customer Relationship}

Table 4 presents the SWOT analysis on customer relationships aspects of Top Selfie BMC. The relationship with tourists is directly spontaneous since there is no systemic pattern with tour operator groups. The communication strategy is conducted by providing the best possible service and hope that there will be positive feedback on social media. According to the survey results, $47 \%$ of respondents used selfie photo services, while tourist interaction with stalls was $24 \%$. Contact between customers and service providers affects overall satisfaction and experience (Wirtz and Jerger, 2016). A feedback instrument is needed to determine the extent of service ratings provided (Sheehan et al., 2007), allows obtaining useful feedback for the organization (del Mar Gálvez-Rodríguez et al., 2020). This instrument can use developing information technology such as the comment feature, or testimonials on existing social media. Based on Table 4, the strategies that can be applied in the Customer Relationship aspect are the Turn Around (W-O), which can be achieved by increasing the capacity and standardizing services as well as making tourist feedback instruments. Managers can encourage the promotional effect by building information technology networks such as free wi-fi facilities on-site to facilitate the sharing of pictures to social networks.

\section{Revenue Streams}

Table 5 shows the SWOT analysis on revenue streams aspects of BMC. It can be figures out from Table 5 that the revenue streams of Top Selfie's are from entrance tickets and parking services. The money in circulation in Top Selfie is quite large, and this shows that tourist attraction has economic benefits for the community. This is in line with research (Ma et al., (2019) and Qian et al. (2017) which has shown that ecotourism is more effective than other local economic sectors in promoting wellbeing and protecting biodiversity. Therefore, the strategy to increase Revenue Streams is Turn Around (W-O), which is achieved by optimizing the potential of unmanaged sources and building collaborative networks. Managers have to explore potential sources of revenue that have not been worked on, such as creating advertising/promotion space, souvenirs, culinary.

\section{Key Resources}

Table 6 displays the SWOT analysis of key resources aspects of BMC Top Selfie. Table 6 depicts the natural factors and a selfie photo spot affected tourist satisfaction in Top Selfie. It is supported by the survey as presented in Figure 2, which resulted $67 \%$ of respondents stated that the motivation for traveling is to refresh and see the natural scenery, about $32 \%$ is to take selfies, and only $1 \%$ answered with the other motivations. Managers have to raise awareness of all elements towards forest resources and consolidate all business actors to increase awareness of natural reserves (Masud et al., 2017) and realize the sustainability of tourism businesses. Sustainability is the central goal for which careful planning and management is necessary.

Table 5. SWOT Analysis on revenue streams aspects of BMC Top Selfie

\begin{tabular}{|c|c|c|c|}
\hline $\begin{array}{l}\text { Strength } \\
(\mathrm{S})\end{array}$ & $\begin{array}{c}\text { Weakness } \\
(\mathrm{W})\end{array}$ & $\begin{array}{l}\text { Opportunity } \\
\text { (O) }\end{array}$ & $\begin{array}{l}\text { Threat } \\
(\mathrm{T})\end{array}$ \\
\hline $\begin{array}{l}\text { Revenue } \\
\text { sources from } \\
\text { large tickets } \\
\text { and parking }\end{array}$ & $\begin{array}{l}\text { 1. Revenue is } \\
\text { only from } \\
\text { ticket } \\
2 . \text { Lack of } \\
\text { revenue } \\
\text { variation }\end{array}$ & $\begin{array}{l}\text { Revenue from } \\
\text { advertising } \\
\text { space, } \\
\text { souvenirs and } \\
\text { culinary }\end{array}$ & $\begin{array}{l}\text { 1. Similar } \\
\text { competitors } \\
2 . \text { The lack of } \\
\text { innovation } \\
\text { threatens the } \\
\text { visitor number }\end{array}$ \\
\hline
\end{tabular}

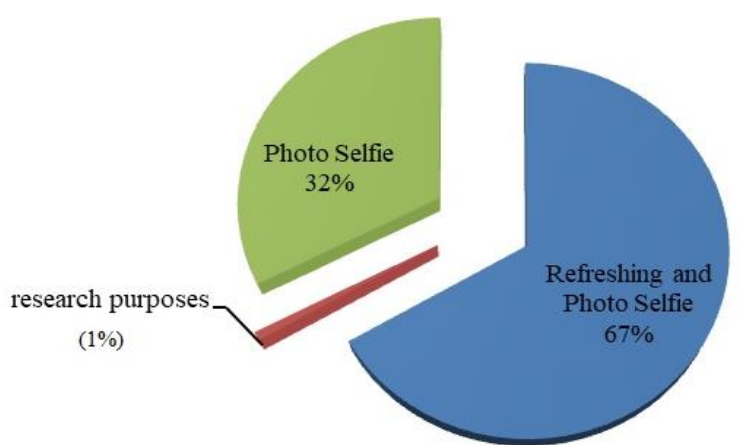

Figure 3. Motivation of visiting the Kragilan Top-Selfie tourist spot

To mitigate the impact of Top Selfie Tourism activities, National Park Agency has to increase its role and function as a companion and supervisor. It is justified, therefore, the intervention by the public authorities in order to regulate the use of natural resources, in order to avoid the "tragedy of the common properties" (Kherrour et al., 2018). The regulations governing utilization in National Park have to be fully complied, such as the implementation of carrying capacity and restrictions on tourism infrastructure buildings. There have not been any restrictions on visits based on the calculation of the carrying capacity in Top Selfie. Visits exceeding the carrying capacity have the potential to destroy resources and reduce satisfaction. When the holiday peak looks very crowded, even finding a clean photo angle is quite difficult. Based on Table 6, strategy should be 
applied is the combination of Aggressive (S-O) and Diversification (S-T). The strength and opportunity for natural resources are very great, but the damage threat is also great. Therefore, the strategy is emphasized on maintaining natural resources and arranging selfie photo spot. To avoid the tourists' accumulation, it is also necessary to arrange the flow of the visit.

\section{Key Activities}

The Top Selfie tourism is well perceived by visitors, supported by the survey result of the satisfaction level where as many as $2 \%$ were very satisfied, $41 \%$ satisfied, $47 \%$ said it was enough, $10 \%$ were not satisfied and none expressed dissatisfaction. A high satisfaction level has to be managed by maintaining the quality of the available resources, both artificial and natural. In eco-tourism, general satisfaction influences the intentions of recommending and returning to the destination (Carvache-Franco et. al., 2020). Common management can be observed in the tourism services sector since there are rules for each family to keep a watch at the counter/parking lot/restrooms etc. All residents of Kragilan Hamlet, made up of 74 families, will become "shareholders" of Top Selfie. It is necessary to increase the capacity of members in order to maintain competitiveness (Buhalis, 2000; Christian and Marco, 2012) with other places, both in managerial capabilities, technical expertise, and the eco-preneurships capacity. The poor quality of human resources is reflected in the level of education, from 53 management there are only 2 graduates from high school, 9 from junior high school, and 42 from elementary school. The strategy for Key Activities is the Turn Around (W-O) since it is emphasized on optimizing weak factors, such as capacity building programs and conducting science-based business studies. To improve the quality of service and value offered, it is necessary to conduct research and development.

Table 6. SWOT analysis of key resources aspects of BMC Top Selfie

\begin{tabular}{|c|c|c|c|}
\hline Strength $(\mathrm{S})$ & Weakness $(\mathrm{W})$ & Opportunity $(\mathrm{O})$ & Threat $(\mathrm{T})$ \\
\hline $\begin{array}{l}\text { 1. Natural Resource } \\
\text { 2. Selfie photo spot }\end{array}$ & 1. Natural resources are vulnerable & 1. High tourist satisfaction & Degradation of natural resources \\
& 2. There is no carrying capacity setting & 2. Trend interest in ecotourism & \\
\hline
\end{tabular}

Table 7. SWOT Analysis on Key Activities Aspects of BMC Top Selfie

\begin{tabular}{|l|l|l|l|}
\hline \multicolumn{1}{|c|}{ Strength $(\mathrm{S})$} & \multicolumn{1}{|c|}{ Weakness $(\mathrm{W})$} & \multicolumn{1}{c|}{ Opportunity $(\mathrm{O})$} & \multicolumn{1}{c|}{ Threat $(\mathrm{T})$} \\
\hline $\begin{array}{l}\text { 1. Community-Based Ecotourism } \\
\text { 2. Communal management }\end{array}$ & $\begin{array}{l}\text { 1. Human resource quality is lacking } \\
\text { 2. Development is not scientific-based }\end{array}$ & $\begin{array}{l}\text { 1. Community-Based Ecotourism has great support } \\
\text { 2. Selfie culture still becomes a trend }\end{array}$ & $\begin{array}{l}\text { Similar } \\
\text { competitors }\end{array}$ \\
\hline
\end{tabular}

Table 8. SWOT analysis of BMC Top Selfie key partners aspects

\begin{tabular}{|l|l|l|l|}
\hline \multicolumn{1}{|c|}{ Strength (S) } & \multicolumn{1}{|c|}{ Weakness (W) } & \multicolumn{1}{c|}{ Opportunity (O) } \\
\hline $\begin{array}{l}\text { Partnering with the Government } \\
\text { Local Service providers }\end{array}$ & $\begin{array}{l}\text { There are still sectoral egos among stakeholders } \\
\text { Low HR capacity }\end{array}$ & $\begin{array}{l}\text { Funding support } \\
\text { Assistance from universities or other key partners }\end{array}$ & $\begin{array}{l}\text { Overlapping } \\
\text { interests }\end{array}$ \\
\hline
\end{tabular}

Table 9. SWOT analysis on cost structure aspects of BMC Top Selfie

\begin{tabular}{|c|c|c|c|}
\hline Strength $(\mathrm{S})$ & Weakness $(\mathrm{W})$ & Opportunity $(\mathrm{O})$ & Threat $(\mathrm{T})$ \\
\hline $\begin{array}{c}\text { All expenditures are } \\
\text { formulated by all citizens }\end{array}$ & $\begin{array}{c}\text { There is no capacity building and } \\
\text { research development budget }\end{array}$ & $\begin{array}{c}\text { Opportunities for funding support from } \\
\text { the State/ Village Fund }\end{array}$ & $\begin{array}{c}\text { Financing operations are } \\
\text { increasing }\end{array}$ \\
\hline
\end{tabular}

\section{Key Partners}

The SWOT analysis of BMC Top Selfie key partners aspects is presented in Table 8. Top Selfie's Key Partners currently consist of three groups, namely National Park Agency, Village Government, and service provider groups. The National Park Agency becomes an important partner in its capacity as "owner" of the national park. In terms of funding support, the National Park Agency also allocates a budget to support the implementation of Top Selfie tourism. Village Government becomes an important partner because of its role in the development of social communities. Furthermore, support from the local government is needed to integrate the area into other sectors, both in terms of infrastructure, financing, strengthening of social institutions, and promotion of tourism. The next Key Partners is The Service Providers, and this group plays an important role in complementing Top Selfie tourism. There are at least 118 photo service providers from nearby villages. Of the 118 top selfie photographers, 106 were high school graduates, while the remaining 12 were from junior high school. Another important service is the Photo Spot provider. It was identified that there were 38 photo spots on the land owned by residents bordering the Top Selfie forest area. Since these photographers work individually, their development is not currently integrated into Pokdarwis/ Top Selfie. The management synergy inside and outside the forest is not strong because of the sectorial ego. Besides the existing Key Partners, it is necessary to build opportunities for collaboration with universities or business actors. Furthermore, business actors or academics can fill this space to improve the quality of human resources and simultaneously provide business assistance.

Therefore, based on Table 8, the Turn Around (W-O) can be suggested as the development strategy. It strengthens the role of existing stakeholders and builds partnerships with universities/business partners in the context of research, assistance, and capacity building. Also, it is important to build collaboration and togetherness with key partners to fight off sectorial egos.

\section{Cost Structure}

Table 9 presents the SWOT analysis on cost structure aspects of BMC Top Selfie. The revenue generated is divided into operational costs, management fees, profit sharing, and development. Operational costs are monthly routine expenses incurred to pay duty fees for officers and routine expenses for purchasing tools and supporting materials. Once the operating costs are covered, the remaining (net) income is divided into administration fees of $10 \%, 20 \%$ for development reserves, and $70 \%$ for 
production sharing with the communities. Therefore, each family receives money from profit sharing every month. When considering the composition of the educational attainment, the allocation of resources for capacity building for soft and technical skills is crucial. Also, the budget allocation for research and development is not visible in the current cost structure. Innovation and the management of trial and error are not science-based since it poses a major threat to the sustainability of natural resources. it should be encouraged local economies: a very important aspect is the self-financing, which should support the state funding, pursuing a national park business model (Marlina et al., 2020). Furthermore, National Park Agency and Village Government have the potential to reduce the cost structure burden through the State Budget or Fund held for infrastructure development.

Hence, to anticipate the increasing operational costs based on Table 9, the Turn Around (W-O) strategy is used, where it communicates and collaborates with the National Park Agency and the village government.

\section{Business Model Canvas Development}

The prototype design of the BMC Top Selfie business model is shown in Figure 4, which is a combination of the old business model (black box) and its improvements (red box). Figure 4 considers every aspect of the old business model has been added or innovated according to the analysis of internal and external factors.

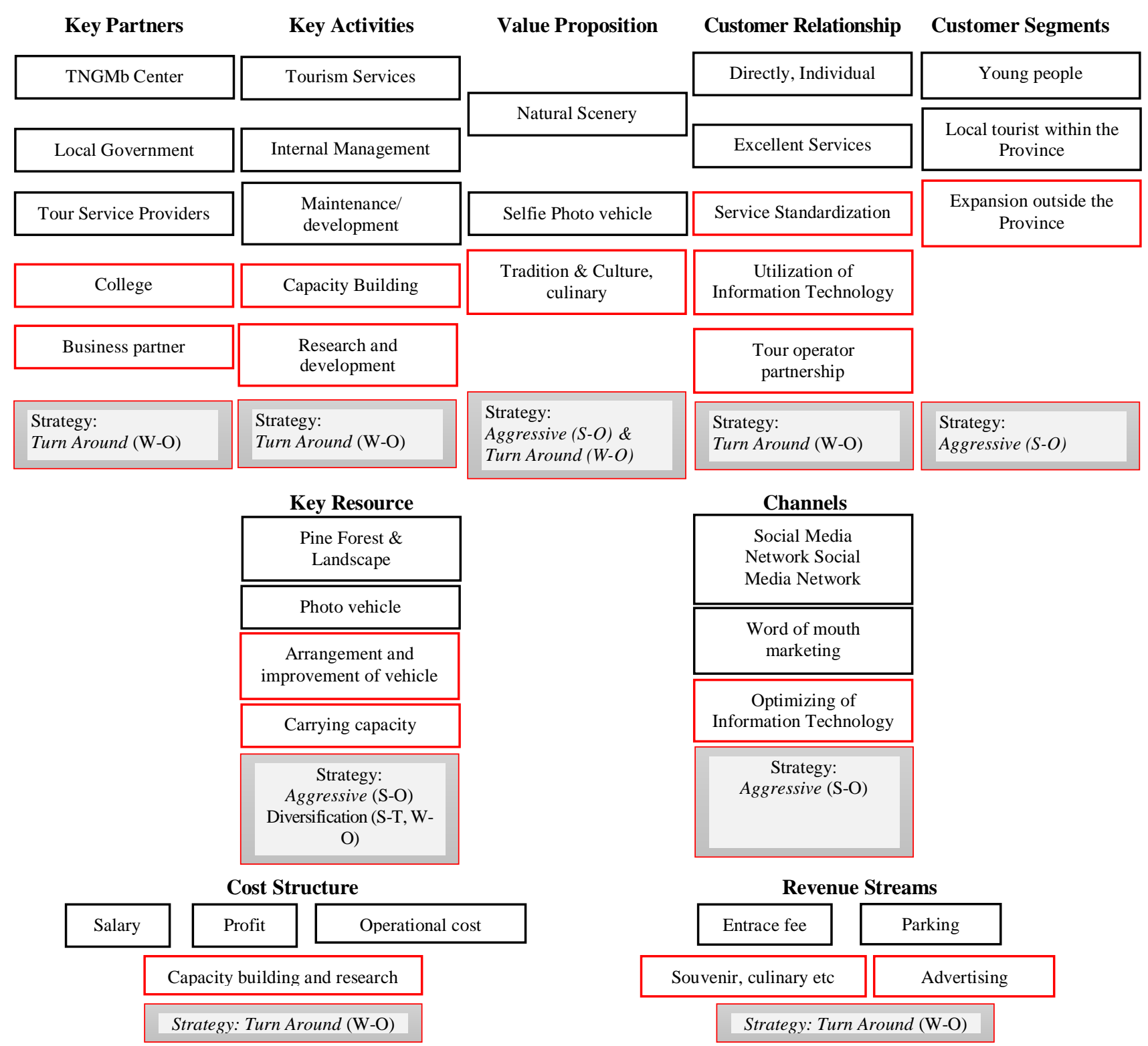

Note: $\square$ Old Business Model Canvas; $\square$ New or Improved Business Model

Figure 4. BMC Top Selfie Tourism Development Business Model

\section{CONCLUSION}

Top Selfie's BMC analysis produces various strategies. However, there has been a "meeting point" between market expectations, the value offered, and the promotional channels used. This can be achieved by using the nature-oriented tourism opportunities that are still very open. The most important resource aspect is a combined strategy of Aggressive (S$\mathrm{O}$ ) and Diversification (S-T) because the factors of strength, opportunity, and threat were equal. 
Therefore, the strategy was aimed at mitigating damage impact programs, conserving natural resources, and arranging visits and selfie vehicles/ photo spot. On the other hand, the cost structure, customer relations, key activities, and partners of turn around business strategy aspects focus on improving weak elements to boost revenue streams.

\section{REFERENCES}

Buhalis, D. (2000). Tourism and information technologies: Past, present and future. Tourism Recreation Research, 25(1), 41-58. https://doi.org/10.1080/02508281.2000.11014899

Butler, R.W. (1980). The concept of a tourist area cycle of evolution: Implications for management of resources. Canadian Geographer / Le Géographe Canadien, 24(1), 5-12. https://doi.org/10.1111/j.1541-0064.1980.tb00970.x

Carvache-Franco, M., Carvache-Franco, O., Carvache-Franco, W., \& Villagómez-Buele, C. (2020). From satisfaction in eco-tourism to loyalty in a national park. Geojournal of Tourism and Geosites, 28(1), 191-202. https://doi.org/10.30892/gtg.28115-462

Carvache-Franco, M., Carvache-Franco, O., Carvache-Franco, W., Villagómez-Buele, C., \& Saltos-Layana, A. (2020). Sociodemographic aspects and their relationship with the ecotourists' motivations in a coastal national park from Ecuador. Geojournal of Tourism and Geosites, 31(3), 1075-1082. https://doi.org/10.30892/gtg.31320-543

Cavagnaro, E., Staffieri, S., \& Postma, A. (2018). Understanding millennials' tourism experience: values and meaning to travel as a key for identifying target clusters for youth (sustainable) tourism. Journal of Tourism Futures, 4(1), 31-42. https://doi.org/10.1108/JTF-12-2017-0058

Chakrabarty, P., Pan, S., \& Mandal, R. (2019). Promoting wildlife tourism on geotourism landscape: A study in Manas and Kaziranga National Parks of Assam, India. Geojournal of Tourism and Geosites, 24(1), 189-200. https://doi.org/10.30892/gtg.24115-352

Christian, N., \& Marco, M. (2012). The role of human resources in business model performance: the case of network-based companies. Journal of Human Resource Costing \& Accounting, 16(2), 142-164. https://doi.org/10.1108/14013381211284254

Cobbinah, P.B., Amenuvor, D., Black, R., \& Peprah, C. (2017). Ecotourism in the Kakum Conservation Area, Ghana: Local politics, practice and outcome. Journal of Outdoor Recreation and Tourism, 20, 34-44. https://doi.org/10.1016/j.jort.2017.09.003

Cochard, R. (2017). Scaling the Costs of Natural Ecosystem Degradation and Biodiversity Losses in Aceh Province, Sumatra. In Redefining Diversity and Dynamics of Natural Resources Management in Asia. https://doi.org/10.1016/B978-0-12-805454-3.00013-X

Daou, A., Mallat, C., Chammas, G., Cerantola, N., Kayed, S., \& Saliba, N.A. (2020). The Ecocanvas as a business model canvas for a circular economy. Journal of Cleaner Production, 258, 120938 (1-12). https://doi.org/10.1016/j.jclepro.2020.120938

Del Mar Gálvez-Rodríguez, M., Alonso-Cañadas, J., Haro-de-Rosario, A., \& Caba-Pérez, C. (2020). Exploring best practices for online engagement via Facebook with local destination management organisations (DMOs) in Europe: A longitudinal analysis. Tourism Management Perspectives, 34, 100636 (1-11). https://doi.org/https://doi.org/10.1016/j.tmp.2020.100636

Dwyer, L., \& Kim, C. (2003). Destination Competitiveness: Determinants and Indicators. Current Issues in Tourism, 6(5), 369-414. https://doi.org/10.1080/13683500308667962

Fan, D.X.F., Buhalis, D., \& Lin, B. (2019). A tourist typology of online and face-to-face social contact: Destination immersion and tourism encapsulation/decapsulation. Annals of Tourism Research, 78, 102757 (1-16). https://doi.org/https://doi.org/10.1016/j.annals.2019.102757

Hajli, N., Wang, Y., \& Tajvidi, M. (2018). Travel envy on social networking sites. Annals of Tourism Research, 73, 184-189. https://doi.org/10.1016/j.annals.2018.05.006

Joyce, A., \& Paquin, R.L. (2016). The triple layered business model canvas: A tool to design more sustainable business models. Journal of Cleaner Production, 135, 1474-1486. https://doi.org/https://doi.org/10.1016/j.jclepro.2016.06.067

Kherrour, L., Rezzaz, M.A., \& Hattab, S. (2018). Rehabilitation of geographical areas for a tourist development the case of batna region's mountains (Algeria). Geojournal of Tourism and Geosites. https://doi.org/10.30892/gtg.22215-302

Kodir, A., Tanjung, A., Sumarmi, Ahmad, R., \& Simanjuntak, T.B. (2019). Tourism governance in komodo national park, Indonesia: Blessing or curse? Geojournal of Tourism and Geosites, 27(4), 1401-1417. https://doi.org/10.30892/gtg.27424-443

Lonn, P., Mizoue, N., Ota, T., Kajisa, T., \& Yoshida, S. (2018). Evaluating the Contribution of Community-based Ecotourism (CBET) to Household Income and Livelihood Changes: A Case Study of the Chambok CBET Program in Cambodia. Ecological Economics, 151, 62-69. https://doi.org/https://doi.org/10.1016/j.ecolecon.2018.04.036

Ma, B., Yin, R., Zheng, J., Wen, Y., \& Hou, Y. (2019). Estimating the social and ecological impact of community-based ecotourism in giant panda habitats. Journal of Environmental Management, 250, 109506 (1-8). https://doi.org/https://doi.org/10.1016/j.jenvman.2019.109506

Marlina, Sumarmi, \& Astina, I.K. (2020). Sustainable marine ecotourism management: A case of marine resource conservation based on local wisdom of bajo mola community in wakatobi national park. Geojournal of Tourism and Geosites. https://doi.org/10.30892/GTG.32419-575

Masud, M.M., Aldakhil, A.M., Nassani, A.A., \& Azam, M.N. (2017). Community-based ecotourism management for sustainable development of marine protected areas in Malaysia. Ocean \& Coastal Management, 136, 104-112. https://doi.org/https://doi.org/10.1016/j.ocecoaman.2016.11.023

Oliveira, T., Araujo, B., \& Tam, C. (2020). Why do people share their travel experiences on social media? Tourism Management, 78,104041 (1-14). https://doi.org/https://doi.org/10.1016/j.tourman.2019.104041

Osterwalder, A., Pigneur, Y., \& Tucci, C. L. (2010). Clarifying Business Models: Origins, Present, and Future of the Concept. Communications of the Association for Information Systems, 16(1), 1-40. https://doi.org/10.17705/1CAIS.01601

Perez, P.L. (2018). Living with the problem of national parks: Indigenous critique of Philippine environmental policy. Thesis Eleven, 145(1), 58-76. https://doi.org/10.1177/0725513618763840

Qian, C., Sasaki, N., Jourdain, D., Kim, S.M., \& Shivakoti, P.G. (2017). Local livelihood under different governances of tourism development in China - A case study of Huangshan mountain area. Tourism Management, 61, 221-233. https:/doi.org/https:/doi.org/10.1016/j.tourman.2017.01.006

Ryan, T.P. (2013). Sample Size Determination and Power. In Sample Size Determination and Power. https://doi.org/10.1002/9781118439241

Sanagustín Fons, M.V., Fierro, J.A.M., \& Patiño, M.G.Y. (2011). Rural tourism: A sustainable alternative. Applied Energy, 88(2), $551-557$. https://doi.org/https://doi.org/10.1016/j.apenergy.2010.08.031

Sheehan, L., Ritchie, J.R.B., \& Hudson, S. (2007). The Destination Promotion Triad: Understanding Asymmetric Stakeholder Interdependencies Among the City, Hotels, and DMO. Journal of Travel Research, 46(1), 64-74. https://doi.org/10.1177/0047287507302383

Shi, F., Weaver, D., Zhao, Y., Huang, M.F., Tang, C., \& Liu, Y. (2019). Toward an ecological civilization: Mass comprehensive ecotourism indications among domestic visitors to a Chinese wetland protected area. Tourism Management, 70, 59-68. https://doi.org/https://doi.org/ 10.1016/j.tourman.2018.07.011

Toro-Jarrín, M.A., Ponce-Jaramillo, I.E., \& Güemes-Castorena, D. (2016). Methodology for the of building process integration of Business Model Canvas and Technological Roadmap. Technological Forecasting and Social Change, 110, 213-225. https://doi.org/https://doi.org/ 10.1016/j.techfore.2016.01.009

Wirtz, J., \& Jerger, C. (2016). Managing service employees: literature review, expert opinions, and research directions. The Service Industries Journal, 36(15-16), 757-788. https://doi.org/10.1080/02642069.2016.1278432

Yoon, Y., \& Uysal, M. (2005). An examination of the effects of motivation and satisfaction on destination loyalty: a structural model. Tourism Management, 26(1), 45-56. https://doi.org/https://doi.org/10.1016/j.tourman.2003.08.016 